\title{
IN DENNE BEGINNE
}

Zittend te midden van opmerkingen en beschouwingen over Genesis 1 1 ) krijg ik ook onder ogen een artikel van Carl A. Keller met het opschrift: Existentielle und heilsgeschichtliche Deutung der Schöpfungsgeschichte (Gnl: 1-2:4).2) Al naar des lezers eigen gezindheid gaat hij met meer of minder belangstelling dit artikel lezen. Met die gezindheid bedoel ik hoe hij staat tegenover existentialisme of existentiefilosofie en tegenover „Heilsgeschichte" en in hoeverre hij de scheppingsgeschiedenis vatbaar acht voor een bewerking vanuit deze gezichtspunten. „In hoeverre"-want het streven om, uitgaande van ervaring en beleving van zichzelf als zijnde in het bestaan, al het andere te beschouwen in betrekking tot dit concreet-individueel menselijk bestaan, als ook het andere streven: Gods heilsbedoelingen in de historie op te merken, vindt bij ons als van-ons-lot-bewuste mensen wel waardering, maar de principia, waarvan zo 'n streven uitgaat, moeten ook aanvaardbaar zijn! Wanneer Keller zegt dat deze strevingen staan tegenover de historisch-critische en historiserende opvattingen, beseffen we terstond dat de „Deutungen” die hij bespreekt ons persoonlijk beter kunnen helpen in onze ,existentie" dan de koude historische critiek die spreekt over dingen waarvan ze zelf niets gelooft (bijv. oudtestamentische heilsbeloften). Als echter in de door Keller gemaakte tegenstelling ook de historische aanvaarding o.a. van Genesis 1 wordt betrokken onder de disqualificerende uitdrukking ,historiserende", komen we onwillekeurig in verzet alsof er geen goede historische opvatting kon zijn zonder historisering en met inachtneming van ons persoonlijk heilsbelang. Wie de Bijbel als „heilsgeschichtlich" leest, behoeft toch nog niet de historie „nur als Hülle für die Heilsveranstaltung Gottes" aan te zien (sic Keller)?

Bij verdere lezing van Kellers artikel bemerkt men dat er in de door hem vermelde „Deutungen” niet veel van de historie overblijft. Richardson3 ) Barth4), Meess), Zimmerli6), Bonhoeffer7), Vischer8) en Fieg9) passeren de revue. Richardson spreekt van de gelijken is sen uit Genesis, 
Barth van de vorm van geschiedenis die „,unhistorisch" beter nog ,praehistorisch" en naar haar wezen $s$ a g e is. Mees doorbreekt de „falsche literalistische Deutungen der heiligen Texte" om een verloren oeroude traditie terug te vinden, waarbij intussen ,alles Geschichtliches" verdwijnt achter de grote monistisch-naturalistische „Mythus”. Zimmerli laat de Bijbelse getuigen mythen, voorstellingen en begrippen van hun tijd opnemen. Bonhoeffer zegt: „Der Anfang der Schopfung ist nicht geschichtlich”.

Uit deze "Ungeschichtlichkeit" worden schone gedachten afgeleid, bijv. dat wij afhankelijk zijn van God (Zimmerli, Richardson, Fieg), dat God onze levensdis dekt n.l. de dis des HEREN van het genadeverbond (!) (Barth), dat God goed is (Vischer). Maar deze schone gedachten missen een werkelijke bodem, als ze uit mythen en sagen worden afgeleid-gelukkig zijn ze ons anderszins niet onbekend! Vroom klinkt het als gezegd wordt dat de kerk de scheppingsgeschiedenis ,nur vom Ende her, von Christus her" kan lezen (Bonhoeffer) en dat slechts in Christus waar is, wat in Gen. 1 staat (Vischer). (We vinden soortgelijke gedachten trouwens ook bij Noordtiijlu,.) Het komt mij logischer voor juist andersom alles wat op Gen. 1 volgt in het licht van dit eerste bijbelhoofdstuk te zien. Bij de schepping is er niet per se een "Bezogenheit auf den Bund der Gnade” (Barth). Maar misschien word ik nu beschuldigd van infralapsarisme ..... Of-wás er zonde bij de schepping? Barth spreekt van een verworpen werkelijkheid, van een „Ihm fremden und feindseligen Geschöpfes"! We komen op deze vraag straks terug.

Het artikel van Keller stelt diep teleur, omdat het geen waarde hecht aan exegese. Dan kan ik van de historische critiek, als ik ze lees met het critisch oog van mijn geloof, meer leren. Dat was tenminste exegeseal was ze onaanvaardbaar. En voor die verwaarlozing van de exegese schaamt men zich ook niet! Keller zegt ronduit: een uitlegging wordt eerst interessant door wat een uitlegger op grond van zijn praemissen en vraagstellingen ,in den Text hineinlegt"!! Tegen deze woorden tekenen we een heftig protest aan! We wenden ons af van dergelijke filosofische bespiegelingen en speculaties om terug te keren tot exegese d.w.z. u it legkunde !

Intussen ben ik me er terdege van bewust dat het zeer moeilijk is en allicht onmogelijk zal blijken te zijn een dusdanige exegese van de eerste twee hoofdstukken van het boek Genesis te geven, dat alles wat daarin staat volkomen duidelijk voor ons wordt. Er zullen zeker vragen over blijven, vragen over wat in deze hoofdstukken staat en ook vragen over wat er niet in staat. Want we willen méér weten dan in deze hoofdstukken ver- 
meld wordt. Dit streven kan veroordelenswaardig zijn als een willen indringen in hetgeen God ons niet heeft willen openbaren, maar het kan ook zijn een ernstig pogen om bij de erkenning van ,de vaststaande feiten”, die resultaten zijn van de hedendaagse wetenschap, ook te aanvaarden, wat de Heilige Schrift zegt. Hoe wij deze hoofdstukken ook benaderen, of we ze "naief" lezen of bedenken dat we met anthropomorphismen te doen hebben-dit zijn homiletische questies-de H. Schrift van haar kant, ook Gen. 1, is openbaring en geeft ons mededeling van waarheid. Van de resultaten der zoekende en wisselende menselijke wetenschap kan dit nimmer in zo 'n absolute zin gezegd worden.

Nu zijn er in het O.T. nog andere uitspraken over de schepping. Maar desondanks blijven er nog vragen over, ja, worden ze zelfs vermeerderd. De grootste moeilijkheid is deze dat Gen. 1 openbaring geeft over een wonderwerk Gods. Daarom kunnen we alleen door het geloof verstaan dat de "aeonen" door het woord Gods tot stand gebracht zijn, zodat "to blepomenon" niet ontstaan is uit ",phaenomena" (Hebr. 11:3). Dit betekent echter niet, dat het geen zin zou hebben wat ons geopenbaard is nauwkeurig te $1 \mathrm{e} \mathrm{z}$ e $\mathrm{n}$ en te ontvouwen-de taak der exegese.

De hernieude belangstelling voor Gen. 1 en 2 vindt wel haar oorsprong in de resultaten der hedendaagse wetenschap: de geschiedvorsching, de archeologie en de natuurwetenschappen. Zijn deze resultaten in overeenstemming te brengen met de schriftgegevens? Eén van de moeilijkheden is $\mathrm{de} \mathrm{tijd.} \mathrm{Er} \mathrm{zijn} \mathrm{er} \mathrm{meer,} \mathrm{maar} \mathrm{we} \mathrm{beperken} \mathrm{ons} \mathrm{in} \mathrm{dit} \mathrm{artikel}$ tot deze alleen.

De wetenschap ,gooit”, zo wordt wel disqualificerend gezegd, met eeuwen. Is de Bijbel daar niet veel spaarzamer mee?! Komt de schriftgelovige niet in een noodtoestand die we als ,tijdnood" kunnen karakterizeren? Schier dagelijks lezen we in rapporten van ouderdommen van millioenen jaren. Om een recent voorbeeld te noemen: in de Negeb, het zuidelijk deel van de staat Israel, niet ver van de vindplaats der beroemde DodeZeerollen, is verleden jaar een haaientand gevonden, waarvan de ouderdom door den directeur van de geologische dienst van Israël werd vastgesteld op zeventig millioen jaar. Hij zal wel van de C-14-methode gebruik gemaakt hebben, welke methode als betrouwbaar wordt aangenomen. De opgravers waren dus op een phosphaatneerslag gestoten, die overblijfselen bevatte van zeedieren uit anti-diluvium-tijd.11)

Wat hiervan te zeggen als men gebogen zit over Gen. 1 ?

De geschiedvorsching brengt wel in minder grote moeilijkheden. Maar als ze ons leert dat de oudste culturen verder dan drie millennia voor 
Chr. reeds een hoogte hadden bereikt, waaraan een eeuwenlange periode van ontwikkeling vooraf moet zijn gegaan, komt toch ook hier de vraag op of de Bijbel zoveel tijdruimte geeft. We komen hier bij de vraag: wat zegt de Bijbelse chronologie, of liever: hoe moeten de chronologische gegevens uit de Bijbel geïnterpreteerd worden.

We vinden zulke gegevens in Gen. 11. Daar worden de nakomelingen van Sem opgesomd in een rechtdoorlopende afstammingslijn van vader op zoon tot Abraham toe. Talrijke zijlijnen worden niet vermeld. De eerste na Sem is Arpachsad, die als hij 35 jaar geleefd heeft, Selah verwekt. Zoo wordt van elke volgende stamvader gezegd op welke leeftijd hij een zoon krijgt. Met deze gegevens kunnen we een tabel opzetten, die volgens Gen. 11:10 beginnen kan met: het jaar 3 na de Vloed: geboorte van Arpachsad; Sem is 100 jaar. Daar van elke vader ook weer gezegd wordt hoe lang hij leeft na de geboorte van zijn oudste zoon, kunnen we in deze tabel ook de sterfdata opnemen. We nemen deze tabel op om duidelijk te kunnen laten zien welke eigenaardige resultaten we dan krijgen. De tabel ziet er als volgt uit:

jaren na de Vloed:

3 Geboorte van Arpachsad.

$\begin{aligned} 38 & \text { Geboorte van Selah } \\ 68 & \text { Geboorte van Heber } \\ 102 & \text { Geboorte van Peleg } \\ 132 & \text { Geboorte van Rehu } \\ 164 & \text { Geboorte van Serug } \\ 194 & \text { Geboorte van Nahor } \\ 223 & \text { Geboorte van Terah } \\ 293 & \text { Geboorte van Abraham in Ur12) } \\ 341 & \text { Dood van Peleg } \\ 342 & \text { Dood van Nahor } \\ 350 & \text { Dood van Noach (Gen. 9:28) } \\ 368 & \text { Vertrek van Abraham uit Haran } \\ 371 & \text { Dood van Rehu } \\ 393 & \text { Geboorte van Isaäk } \\ 394 & \text { Dood van Serug } \\ 428 & \text { Dood van Terah } \\ 441 & \text { Dood van Arpachsad } \\ 453 & \text { Geboorte van Jakob en Esau } \\ 471 & \text { Dood van Selah }\end{aligned}$


503 Dood van Sem

532 Dood van Heber.

De volgende eigenaardigheden springen nu duidelijk in het oog:

1e Toen Abraham geboren werd waren al zijn voorvaderen vanaf en met Noach nog in leven.

2e Toen Jakob en Esau geboren werden waren Selah en Heber, ja zelfs Sem nog in leven.

Zou dit werkelijk de bedoeling van Gen. 11 zijn?

3e Terah sterft 60 jaar na Abrahams vertrek uit Haran. Volgens de rede van Stephanus (Handel 7:4) is Abraham echter na de dood van zijn vader naar Kanaän gegaan.

Een soortgelijke tabel kunnen we opzetten voor de tijd van de schepping tot de zondvloed. Volgens Gen. 5 ziet deze tabel der oudvaders er aldus uit:

jaren na de schepping van de mens

1 Schepping van de mens

130 Geboorte van Seth

235 Geboorte van Enos

325 Geboorte van Kenan

395 Geboorte van Mahalaleël

460 Geboorte van Jered

622 Geboorte van Henoch

687 Geboorte van Methusalah

874 Geboorte van Lamech

930 Dood van Adam

987 Opneming van Henoch

1042 Dood van Seth

1056 Geboorte van Noach

1140 Dood van Enos

1235 Dood van Kenan

1290 Dood van Mahalaleël

1422 Dood van Jered

1556 Geboorte van Sem (Cham en Jafet)13)

1651 Dood van Lamech

1656 Dood van Methusalah. De Zondvloed.

Volgens deze wijze van tellen verloopt er tussen schepping van de mens en de Zondvloed 1656 jaar. Vreemd is weer dat zovele oudvaders tegelijk leefden. Zou dat werkelijk de bedoeling van Gen. 5 zijn? Zou Metuusalah in die Zondvloed omgekomen zijn? 
Het geboortejaar van Abraham kan verder volgens bijbelse gegevens worden gesteld in 1950 of 2165 voor Chr. Volgens bovenstaande telling was dit 293 jaar na de vloed. En de vloed was 1656 jaar na de schepping van de mens. Hier hebben we de berekening waaraan we de lang gangbare opvatting te danken hebben, waarvan we als kinderen zongen in het Kerstversje:

Veertig eeuwen van te voren

werd de Mid'laar ons beloofd.

Men vergelijke hiermee de Joodse jaartelling, die dit jaar, 1956 na Chr, in Okt. opklimt tot 5717 en dus nog lager getal aanneemt voor ,, het bestaan der wereld".

Het is duidelijk dat we met deze getallen niet in het reine kunnen komen met de resultaten der wetenschap. Omdat de tabellen verder bevreemdende resultaten aanwezen kunnen we met recht vragen of de chronologische gegevens van de $H$. Schrift wel zo moeten opgevat worden als boven is gedaan.

Het mag als bekend verondersteld worden dat wijlen prof. dr. C. van Gelderen in het Bijbelsch Handboek van de veronderstelling is uitgegaan dat in Gen. 11, evenals in andere genealogieën, generaties zijn overgeslagen. Zijn bedoeling is deze: als er staat dat Heber een zoon verwekt dan wordt als naam van dien zoon opgegeven de naam van Hebers opvolger als patriarchaal stamhoofd, die verscheidene generaties verder van Heber afstaat dan de zoon dien Heber zelf verwekte. Hebers opvolger als patri rchaal stamhoofd verkreeg deze status bij den dood van Heber. Hij nu heette Peleg. Heber werd 464 jaar. Heber is ook patriarchaal stamhoofd geworden na den dood van Selah en is niet Selahs eerstgeborene, maar de nazaat van Selah in rechte lijn, die hem opvolgt als stamhoofd. Het gevolg van deze hypothese is dat we dan in de bovengegeven tabel veel grotere tussenruimtes verkrijgen tussen de verschillende stamhoofden, want Peleg verschijnt dan op het toenmalige wereldtoneel na Hebers dood en dat is eeuwen later dan in bovengenoemde tabel. Nu moet bij de hypothese van v. Gelderen verder aangenomen worden dat als bijv. Heber sterft óf al de tussenliggende generaties dood zijn en daarom Peleg opvolgt of dat de jongste generatie opvolgt met voorbijgang van de tussenliggende generaties. Beide aannamen lijken vreemd. Toch behoeven we hierom v. Gelderens hypothese niet terzijde te stellen, want het is blijkbaar de bedoeling van Gen. 11 de opeenvolgende stamhoofden te vermelden.

Het resultaat waartoe v. Gelderen komt is dat Abraham geboren wordt ongeveer 2400 jaar na de Vloed.14) 
Hiermee winnen we enkele millennia waarin de ontwikkeling kan vallen der culturen, die in Abrahams tijd reeds zulk een grote hoogte hadden bereikt.

We kunnen de verleiding niet weerstaan hetzelfde experiment toe te passen op de genealogie uit Gen. 5. We nemen aan dat Seth stamhoofd werd bij Adams dood en Adam werd 930 jaar oud. Hoe oud was Seth toen hij stamhoofd werd? Voor het tijdvak van Sem tot Abraham heeft van Gelderen aangenomen dat de opvolgers op 45-jarigen leeftijd opvolgden. Dit komt overeen met het gemiddelde der leeftijden, waarop elk stamhoofd zijn oudsten zoon kreeg. Deze is echter voor de tijd van Adam tot Noach beduidend hoger. Adam was 130 jaar toen Seth geboren werd en Seth 105 jaar toen Enos geboren werd. De leeftijden, waarop de volgende stamhoofden hun zoon krijgen is resp. 90, 70, 65, 162, 65, 187, 280. Hierin is nogal variatie en Noach is al 500 jaar als Sem, Cham en Jafet geboren worden. Dit versterkt ons in de gedachte dat de genealogie de naam geeft van den opvolger. We nemen nu de jaren die elk leefde na de geboorte van den zoon als de tijd gedurende welke hij stamhoofd was. We krijgen dan dat Seth stamhoofd werd in 930. Hij was stamhoofd 807 jaar (Gen. 5:7). Enos wordt dan stamhoofd in 1737 . Kenan in 2542 enz. Noach in 6699 dus 7 millennia na de schepping des mensen. Toen de Vloed kwam was Noach reeds misschien 400 jaar stamhoofd. Abraham werd geboren ongeveer 2400 jaar na den vloed (zie boven) en ongeveer 2000 jaar voor Christus. We krijgen dus voor de voorchristelijke aera een tijdperk van 11 millennia en voor den tijd van de schepping des mensen tot vandaag 13 millennia.

Dit is hypothese!

Maar bij elke hypothese kan gevraagd worden: helpt zij ons iets?

Deze doet dit zeer zeker!

Laten we luisteren naar Ruth Moore die een omstandig en interessant verhaal geeft van de gang der natuurwetenschappen in den jongsten tijdis) en vertelt van de laatste verschuiving van het Noordpoolijs in Zuid-westelijke richting, waarna het ijs smolt en het gebied, dat nu Noord-Amerika heet, voor de mens bewoonbaar werd. Gefossiliseerd hout van de sparrenbomen van Wisconsin, die door deze laatste ijsverschuiving waren bedolven, werd door LIBBY gereduceerd tot pure koolstof, waarna hij dit uitspreidde in de Geigerteller: "Omdat de koolstof (C 14) radioactief was, begon de teller te tikken. Het was bijna alsof de koolstof zijn eigen ouderdom aftelde. En deze ouderdom bleek 11000 jaar te zijn en niet 25000 zoals de wetenschap voordien veronderstelde”. „De mens was dus in het Noorden minder dan 000 jaar geleden op het toneel verschenen." Ook in Duitschland werden 
zulke onderzoeken ingesteld. Ook daar waren door ijsverschuivingen wouden omvergeworpen. Het onderzoek had dezelfde uitslag. Evenzo in Engeland en Ierland. „De essentiële overeenstemming tussen de data sluit in dat de gletchers in Noord-Europa zich in dezelfde tijd terugtrokken als die in Amerika" "C 14 verkleint de tijdsafstand die de huidige mens scheidt van zijn voorouders die in grotten leefden en pijlpunten bewerkten. Het reduceert die afstand tot een vluchtige tienduizend jaar”. „De looddatering laat de ouderdom der aarde enorm toenemen, maar laat de periode die de mens daarop doorbracht verhoudingswijze korter worden".

We merken op dat deze getallen een bevredigende overeenkomst vertonen met de getallen die we boven verkregen uit de genealogieën van Gen. 5 en 11.

Wijlen prof. dr. A. de Bondt van Kampen heeft een onuitgegeven lezing16) besloten met de woorden: het is mijn innige overtuiging dat voortgezette studie, ook in de natuurwetenschappen, ons hoe langer hoe meer zal aantonen, welk een overeenstemming er is tussen de waarheid van het Woord Gods en de resultaten der wetenschap.

Blijkens het bovenstaande krijgt hij gelijk! En dit moet zowel de exegeet als de natuurkundige verblijden!

We begeven ons nu naar een andere vraag. In het voorafgaande sprak ik herhaaldelijk van de schepping des ménsen, niet van dé schepping zonder meer. Is er tussen de schepping (zonder meer) en de schepping des mensen een belangrijk tijdsverschil? Wat zegt Gen. 1 daarvan? Is er tijd verlopen tussen wat in Gen. 1 en 2 en in vs. 3 staat? Verder wordt er gesproken van dagen. Wat betekent dat? En wat zegt de hedendaagse wetenschap daarvan?

Ik moet me weer behelpen met citeren, maar citeer weer ernstige betrouwbare uitspraken.

Prof. dr. C. C. Jonker17), aannemende dat de structuur van de wereld door de zondeval niet zó veranderd is dat de fysische regelmatigheden, die wij nu vinden, bv. in de desintegratie van atoomkernen, toen niet golden, zegt: ,op grond van deze extrapolatie vindt men nu langs verschillende methoden een ouderdom van de aardkorste van ongeveer 2 milliard jaar". Verder spreekt hij over "het heelal". Zich beperkend tot „het heelal in zijn tegenwoordige bewegingsfase" zegt hij: „we kunnen hoogstens zeggen dat het heelal in zijn tegenwoordige bewegingsfase, waarschijnlijk ouder is dan 5 milliard jaar". (een milliard-1000.000.000).

Is hier een geweldig conflict tussen Schrift en Wetenschap? Of is het er slechts tussen een bepaalde schriftinterpretatie en de wetenschap? 
Alvorens hier nader op in te gaan moeten we ons bezinnen op een gevaar dat ons bedreigt. Het valt immers niet te ontkennen, dat er ten aanzien van de dingen die ons nu bezighouden, van de zijde der natuurwetenschappen een zekere druk wordt uitgeoefend op de Theologie en met name op de Exegese van het O.T. Maar deze wetenschappen moeten hun zelfstandigheid behouden! Aan de andere kant nopen de natuurwetenschappen ons de chronologische gegevens met een bredere blik te bezien en onszelf de vraag te stellen of we deze schriftgegevens wel juist hebben geinterpreteerd. Ja, een andere vraag komt op: of we inderdaad met chronologische gegevens te doen hebben, waar dit steeds werd gemeend! Ik bedoel natuurlijk de zes scheppingsdagen.

Reeds het eerste woord van de Bijbel plaatst ons voor moeilijkheden, het woord ,bereesjieth". Gewoon als we zijn aan de vertaling ,in den beginne" verwachten we hier het lidwoord: bareesjieth. $\mathrm{Nu}$ is de lezing zonder lidwoord wel het werk van de Masoreten, maar deze zullen wel niet anders geJaan hebben dan een oude traditionele lezing vastleggen. $\mathrm{Er}$ is een zwak bewijs voor lezing met het lidwoord18), maar te zwak om er op voort te bouwen. Hoe moeten we nu het ontbreken van het lidwoord verklaren? Door de uitdrukking als een status constructus op te vatten (en dan daarbij „,bara” te wijzigen in een infinitief, zoals Kittels uitgave doet, maar wat onnodig is)? Dit doet de Leidse vertaling en daardoor ondergaat de eerste zin van de Bijbel een totale verandering: "Toen God een aanvang maakte met de schepping van hemel en aarde enz". Grammaticaal is dit wel erg correct, maar het is de vraag of we ons deze grammaticale dwang moeten opleggen. De behoefte aan het lidwoord komt op uit óns taalgevoel. Mogelijk hat het Israelietisch taalgevoel geen behoefte aan het lidwoord. Het gebruik van het lidwoord wijkt in het Hebreeuwsch in meer gevallen af van het onze. We nemen daarom liever aan dat we met een verschijnsel van idioom te doen hebben. In Joh. 1 staat ook „en arché” zonder lidwoord. Bedoeld wordt het absolute begin.

$\mathrm{Na}$ deze grammaticale moeilijkheid komen de materiele: waarvan is dit het begin? Van de tijd? Van het bestaan van hemel en aarde? Maar wat is „,hemel en aarde"? Het heelal? Of is hemel de woonplaats Gods? Moet ,hemel" volgens vs. 8 verklaard worden of volgens vs. 14 , in welk geval hij veel groter is. Moeten we ons bij het zoeken naar het antwoord beperken tot ons zonnestelsel? Waar begint het heelal te bestaan-niet wanneer, maar w a a r ? Ik citeer weer dr. Jonker: „Het is ..... duidelijk dat het natuurwetenschappelijk gezien onmogelijk is van het begin van het heelal te spreken. We zouden dan aan moeten geven, wat dit precies betekent: Begint het heelal bij het ontstaan van het eerste atoom of deel van een atoom? 
Welk deeltje is dat? Zijn er onveranderlijke deeltjies, die als oermaterie kunnen optreden? Alle kleine deeltjes die wij kennen, zoals electronen, protonen, neutronen, mesonen en fotonen, zijn niet onveranderlijk, maar gezamenlijk betrokken in een ingewikkeld spel van steeds wisselende verschijningsvormen. Het begrip ,,begin van het heelal”, heeft alleen betekenis als grensbegrip, wanneer het verbonden wordt met de schepping."19) In dit licht moet ik de woorden hierboven gebruikt: ,het absolute begin" weer terug nemen! We worden herinnerd aan de woorden van dr. Noordtzij, dat de woorden ,in den beginne" niet als tijdsbepaling mogen opgevat worden, maar dat deze uitdrukking verklaart dat het begin van het gansche wereldproces heeft bestaan in de schepping van hemel en aarde 20). Bedoelt hij dat deze woorden dus causale betekenis hebben? In ieder geval treffen we hier reeds aan wat we straks nog sterker bij deze geleerde zullen aantreffen en wat ik zou willen noemen: de ont-tijding van uitdrukkingen, die chronologisch lijken d.w.z. er het tijdsbegrip aan ontnemen.

Gewoonlijk wordt Gen. 1:1 opgevat als een mededeling over de schepping van de materie, de substantie, de stof, waaruit de gansche wereld is gevormd.21) Vs. 2 schetst dan de toestand van deze materie. Vs. 3 en v. beschrijft dan hoe God uit de ongeordende materie de geordende wereld vormt. Dit is dan de creatio secunda tegenover de creatio prima uit vs. 1 (en 2).

Ridderbos22) ziet in ,,de hemel en de aarde" van vs. 1 een aanduiding van het heelal, zoals wij het kennen. Hij maakt van vs. 1 geen opschrift van Gen. 1, maar een beginmededeling, een aanduiding van de hoofdinhoud van wat volgt. We vinden dat ook in menige psalm.

In beide gevallen is er dan een zekere tijd verlopen tussen wat in vs. 1 staat en wat in vs. 3 en v. beschreven wordt. Aalders stemt dit volmondig toe23). Ridderbos schijnt ook zo te denken: het is de tijd van de "levenbelemmerende factoren" 24 ). Hoe 1 a $\mathrm{n}$ g deze tijd heeft geduurd valt niet te zeggen. Het is verleidelijk aan te nemen dat hij lang heeft geduurd. Misschien vloeit deze aanname wel voort uit de bovengenoemde druk die de natuurwetenschappen uitoefenen op de exegese. Maar de aldus gevonden tijdsruimte zou beschikbaar komen voor het ,ingewikkeld spel van steeds wisselende verschijningsvormen van de kleinste deeltjes" waarvan dr. Jonker gewaagde-echter niet voor (om concreet te blijven) de in de Negeb gevonden haaientand!

Niet alleen tegen de opvatting dat Gen. 1:1 van de „oersubstantie” spreekt, maar ook tegen de onderscheiding in creatio prima en secunda, die wel door Ridderbos gehandhaafd wordt, trekt Nieboer te velde in zijn 
in het begin van dit artikel genoemde brochure. Na eerst de gangbare verklaring van Gen. $1: 1$ en 2 critisch te hebben bezien en de oorsprong van deze verklaring te hebben aangewezen bij Basilius de Grote en nog verder terug bij Philo van Alexandrië, zegt hij dat de Grieks-wijsgerige ideeën over de structuur van die wereld, speciaal over die van de materie, zich steeds meer hebben vastgezet en verwerkt werden in de verklaring van Gen. 1.25) Verder, dat de verbinding tussen deze exegese en de Griekse denkbeelden op het gebied van de natuur ook na de Reformatie voortdurend bewaard bleef en: ,men bleef Genesis 1 zien als een beknopt schema voor een natuurwetenschappelijke leer over het ontstaan van het heelal, een schema dat men voortdurend moet trachten aan te vullen met en aan te passen bij de werkelijke of vermeende resultaten van de wetenschap"26). Dit laatste $\mathrm{nu}$ keurt Nieboer blijkens zijn redebeleid af.

$\mathrm{Nu}$ is het natuurlijk waar dat de Bijbel geen handboek is voor wetenschappen, welke ook. Toch verkondigt de Bijbel iets. Iets dat W A A R is. We kunnen dit inderdaad niet aanvullen met of aanpassen bij de moderne wetenschap. Toch blijft het zoeken naar overeenstemming ons plagen.

Nieboer wil Gen. 1:1 én 2 tesamen beschouwen als een inleiding tot en samenvatting van de zesdaagse schepping27). Aan deze opvatting staat echter vs. 2 zelf in de weg. Daarin wordt toch beschreven hetzij de toestand van de materie (Aalders) hetzij de toestand van ,levenbelemmerende factoren" (Ridderbos) die aan de creatio secunda voorafging. Nieboer geeft echter van dit vs. de volgende verklaring: „Vs. 2a handelt dus naar onze mening, niet over de toestand, het uiterlijk van de aardbodem in de voortijd-al schemert er daar wel iets van door-maar over de medewerking van de aardbodem in het scheppingswerk." (cursivering van de auteur zelf). „En die medewerking wordt afgewezen” (door vs. 2 is de bedoeling)28), Dit versdeel heeft een negatieve inhoud, terwijl vs. $2 b$ een positieve inhoud heeft: de zwevende Geest Gods. De mededeling van vs. 2 is dan dat de schepping louter Gods werk is geweest. En wat meent Nieboer hiermede te bereiken? „Weggevallen zijn de historisch-geologische gegevens die de gangbare opvatting uit deze verzen meent te kunnen halen"29). „Verdwenen is de vóórschepping van de materie...." Dus: Gen. 1:2 tekent ons geen toestand vóór, maar onder en tijdens (curs. van de auteur) het scheppingswerk Gods 30 ).

Waarlijk niet alleen omdat we hiermede een tijdruimte tussen vs. 1 en 3 verliezen, vraag ik me af of de zo pas geciteerde geweldige conclusies in Nieboers beschouwing en exegese van vs. 2 een hechte basis hebben. 
Hij moge vs. 2 beschouwen zoals hij wil, maar er was dan toch maar een woeste en ledige aarde en een vloed waarop duisternis lag. Daar $\mathrm{s} \mathrm{c}$ h e m e r $\mathrm{t}$ inderdaad iets van door. Het was er vóórdat God sprak er zij licht. En wat zijn exegese betreft-volgens Ridderbos mag aan "woest en ledig" geen al te onschuldige betekenis worden toegekend, maar bij de exegese van Nieboer hebben deze woorden een totaal passieve betekenis. Wat betekenen de woorden tohoe wabohoe? Tohoe komt nog voor I Sam. 12:21 (2 keer), waar tohoe het karakteristiek is der afgoden, die baten noch redden kunnen; Jes. 29:21, waar het betekent iets ijdels, in zichzelf nietswaardigs, al is het intussen instrument van de goddelozen om onrecht te doen. Jes. 40:23, waar het parallel staat met, ,ajin", niets. Job. 6:18 de waterloze wildernis, waar niemand leven kan. Dezelfde betekenis heeft het in Dt. 32:10 en Ps. $107: 40$ en Job 12:24. In Jes. 45:18 wordt het gebruikt in directe tegenstelling met bewoonbaarheid. Dit vs. brengt ons terug naar de schepping evenals Job 26:7, Deze verzen bieden dus meer herhaling dan verklaring van Gen. 1:2. Of het woord inderdaad Jes. 29:13 voorkomt is tekstcritisch onzeker. In Jes. 41:29 betekent het weer het in zichzelf nietswaardige, evenals het woord "wind" dit ook aanduidt. Evenzo ook 44:9. In 49:4 duidt het op het vruchteloze van iets. In 59:4 wordt het gebruikt als in 29:21. In 45:19 om het vergeefse van iets aan te duiden. Ten slotte komt het nog voor in Jer. 4:23, precies als in Gen. $1: 2$ in een woordpaar met bohoe en in Jes. 34:11, waar dezelfde twee woorden parallel gebruikt worden, hoewel niet in woordpaar.

Het woord toohoe komt van een Semietische radix, die ook in het Arabisch en in het Oegarietisch gevonden wordt. Freytagius 31 ) geeft als betekenis van thj: dwalen door woest land, in geestesverwarring zijn, trots, overmoedig zijn (superbire!), pronken, prijken, en vermeld afleidingen van de verbaalstam. met betekenissen als bijv. ondergang, verdwijning, arrogantia, terra deserta. In de Oegarietische texten komt de wortel thw voor in een Baäl en Anat -tekst (67:1.15) en wordt door Gordon vertaalt met "chaos"32).

Bohoe komt dus behalve in Gen. 1:2 slechts twee keer voor en is duidelijk een synoniem van tohoe. Koehler33) vertaalt het met: Leere, Ode, emptiness, wastenes. Het Arabisch aequivalent $\mathrm{bhj}$ betekent volgens Köhler: leer stehn, be empty.

Uit dit overzicht blijkt dat de toestand die in vs. 2 beschreven wordt erger is dan alleen maar een niet medewerken met de schepping (Nieboer), maar dat er weerstanden in liggen, die overwonnen moeten worden, om leven mogelijk te maken. Ik verwijs vooral naar $D t$. 32:10: een tohoe van 
gehuil in de wildernis (genit. epexeg), en Jes. 29:21; 45:18. De Arabische betekenissen: superbire en arrogantia zeggen misschien ook iets, al is het een bewijs van verre. Wat de wateren betreft, Ridderbos verwijst naar Ps. 104 -blijkens vs. 9 hebben we hier wel te denken aan die werken Gods die tot de creatio secunda behoren, maar die ,vijandige" (Job 7:12) wateren waren dan nog onbetoomd in de toestand van vs. 2. Ik geloof niet dat het bij de schepping zo rustig is toegegaan als Nieboer ons wil laten geloven en zoals trouwens meestal gedacht wordt, vgl. ook Job 38:8-11; Spr. 8:29. Ook de in dit verband genoemde tehoom kán zegenrijk zijn (Gen. 49:25; Dt. 33:13), maar ook iets vreselijks als God haar dit toelaat (Gen. 7:11; Ps. 42:8; Hab. 3:10; Ez. 26:19). Maar-God beheerst, overwint deze toestand en het is ook zijn schepping, zoals Ridderbos terecht opmerkt met verwerping van Barths opmerkingen over „feindselige Geschöpfe”. Voor dualisme is er geen plaats in de leer van God in de H. Schrift!

We handhaven dus dat er tussen de creatio prima en de creatio secunda een tijdruimte ligt en waarom zou die niet lang, zeer lang zijn geweest?

We komen nu tot de scheppingsdagen en beperken ons weer tot de vraag betreffende hun tijdsduur en ook betreffende hun tijdelijk zijn.

Er is nl. niet alleen verschil over de vraag hoe lang ze geduurd hebben, maar ook over de vraag of we in de vermelding van de zes scheppingsdagen wel met tijd te doen hebben.

Dat we niet kunnen denken aan dagen van 24 uur heeft prof. Aalders duidelijk uitgesproken35). In jeder geval zijn het werkdagen Gods36). Ook E. Sauer geeft bewijzen dat we niet aan dagen van 24 uur kunnen denken37).

Bekend is de opvatting dat de dagen lange perioden zijn. Van deze concordistische theorie, die streeft naar ,concordia" tussen Gen. 1 en de natuurwetenschap, zegt Noordtzij dat ze geëindigd is met de ontkenning van haar eigen uitgangspunt38) en Ridderbos39) gaat er stilzwijgend aan voorbij, hoewel Sauer er nog een lans voor breekt40). Onder de opvattingen die het tijdsbegrip van de dagen van Gen. 1 handhaven komt het meeste betekenis toe aan die van prof. Aalders. Hij zegt: het waren lichtdagen zonder nachten, lichtcontinua, waarvan het onmogelijk is de preciese duur vast te stellen; ze kunnen langer, maar ook korter dan wat wij gewoon zijn een dag te noemen, zijn geweest4l).

Met deze opvatting blijven we eigenlijk in de moeilijkheid wat betreft de ouderdom der aarde en de zes scheppingsdagen. Dit erkent Aalders zelf ook, maar hij vindt dit niet zo erg en wel om twee redenen: met alleen een hoge ouderdom aan de aarde te kunnen toekennen hebben we de har- 
monie tussen Schrift en wetenschap nog niet gevonden. Er zijn meer problemen42). Dit is zeker waar, maar de ouderdom der aarde is een gewichtige factor in dit probleem. Met een ,,jonge" aarde komen we zeker niet tot harmonie-antwoorden wij-. Dit is echter nog zo zeker niet, zegt Aalders, want, na een bespreking van de natuurwetenschappelijke methoden stelt hij als eindresultaat daarvan dat er, ,in de tot hiertoe verkregen uitkomsten van het natuurwetenschappelijk onderzoek in ieder geval geen genoegzame positieve aanwijzing ligt om aan de scheppingsdagen, van wier duur de $\mathbf{H}$. Schrift zelf ons niets zegt, een zeer grote tijdelijke uitgebreidheid toe te schrijven43).

Prof. Aalders schreef dit in 1932. De proefnemingen zijn intussen voortgegaan. Ik zou graag van een natuurkundige vernemen of de op bl. 252-262 van zijn aangehaald werk door prof. Aalders ontwikkelde bezwaren (nog) geldig zijn.

Ten slotte blijft over te overwegen wat gezegd wordt door hen, die aan de dagen van Gen. 1 het tijdskarakter ontnemen.

We vinden dit zoals Aalders memoreert reeds bij Philo en kerkvaders als Origenes, Athanasius en Augustinus44). Vervolgens bij Noordtzij. Van hem is afkomstig de idee van, ,een $\mathrm{k}$ a d e r ". Nu is Noordtzij met de uiteenzetting van zijn bedoeling met dit woord kader wel wat karig geweest. Hij spreekt echter van ,ideeële orde, waardoor het goddelijk bedoelen met de afzonderlijke daadwerkelijkheden in het volle licht kon treden en des Heeren heerlijkheid helder kon uitstralen"45). Ook zegt hij dat de tijdsindeling een projectie is om ons de heerlijkheid der schepselen te tekenen in het licht van het grote einddoel Gods46). Het zou dus gaan om de heerlijkheid van Schepper en schepsel beide. Maar m.i. wordt bij een chronologische opvatting der zes dagen aan die heerlijkheid in geen enkel opzicht te kort gedaan. Prof. Aalders heeft deze opvatting van een kader bestreden47) maar Ridderbos verdedigt haar weer als een aanvaardbare exegese van Gen. 148). Hij geeft zijn eigen omschrijving van het begrip kader: het verhaal over de schepping in Gen. 1 is geen exact verslag. Er is een achtvoudig weken Gods49) en dit wordt door de geïnspireerde schrijver in een kader gezet: hij verdeelt het over zes dagen en deze verdeling is niet willekeurig50). We hebben met een kunsmatige groepering te doensi ), met een doelbewuste ordening52). Maar m.i. wordt bij een chronologische opvatting van de zes dagen aan dit doel in geen enkel opzicht te kort gedaan. Want of de volgorde der scheppingswerken nu kunstmatig over zes dagen verdeeld of chronologisch beschreven wordt-de volgorde is en blijft de volgorde die we in Gen. 1 aantreffen. Noch om de heerlijk- 
heid van Schepper en schepsel te kunnen aantonen, noch om doelbewuste ordening aan te tonen is de kaderopvatting nodig.

Tot het gezelschap van hen die de zes scheppingsdagen „ont-tijden” behoort ook Nieboer. Philo en Nieboer: trés étonnés de se trouver ensemble. Uitdrukkingen als logische ordes3 ) en logische opzet54) van Gen. 1 worden in dit gezelschap gebruikt! Nieboer zegt: de zes dagen omvatten het hele scheppingswerk, ook wat in Gen. 1:1 en 2 staat, maar ze volgen niet chronologisch op elkaar. Er is geen opeenvolging van scheppingsdagen in den tijd, maar zoals de zevende dag, de rustdag, er altijd geweest is, vóór en na Adam, zo hebben de andere dagen hetzelfde karakter. Het zijn dagen van God, Godsdagen. Hij vermeldt dat Aalders en Bavinck dit laatste ook gezegd hebben. God scheppingsdagen zijn er nog heden, alle tegelijk. God heeft zijn rust-Dag en zijn werk-Dagen alle tegelijk. De eerste dag heeft zijn eerste plaats te danken, niet aan zijn de-eerste-zijn-in-tijdsorde, maar aan de logische opzet van het gehele hoofdstuk. Dit brengt mee, erkent hij, een vervaging van de grens tussen schepping en onderhouding, maar de dogmatiek, zo zegt hij, kan dit onderscheid ook maar moeilijk volhouden5s).

En nu trekt Nieboer hieruit een conclusie, die uit de kaderopvatting niet, althans niet met zulke duidelijke woorden getrokken is, hoewel dit wel kon gedaan worden, een conclusie in verband met het tijdprobleem inzake Gen. 1 en de natuurwetenschappen, een conclusie waarmee dit probleem terzijde gesteld kan worden: „Wanneer natuurwetenschappelijk, en dus voor ieder te controleren, onderzoek ons met aandrang voorhoudt, dat de aarde eerst na zeer lange tijd tot haar tegenwoordige, bewoonbare gedaante is gekomen, is er noch aan het karakter der scheppingsdagen, noch aan wat ons verder over het werken van God is geopenbaard, een argument te ontlenen, om die bewering te bestrijden" 56 ).

Nieboer drukt zich negatief uit! En dat is voorzichtig. Er behoeft geen „concordia" tussen Schrift en natuurwetenschap meer gezocht te worden!

Vooral voor iemand die in moeilijkheden zit heeft deze opvatting van Nieboer veel aanlokkelijks. Maar een groot bezwaar is dat er te duidelijk staat: eerste dag, tweede dag enz. en niet eerste daad, of werk of ,operatio" 57). Ook: het was avond geweest en morgen geweest wijst uitdrukkelijk op opeenvolging van dagen. Wel is het vreemd dat eerst de avond genoemd wordt en dan de morgen. Maar dit moet telkens de avond van dien eigen dag zijn geweest58) en de daarop volgende morgen59). Dan begint de ieuwe dag. 
Als het mogelijk was aan de dagen van Gen. I het temporele karakter en de chronologische betekenis te ontnemen, zouden we haast met Gunkel willen zeggen: die dagen zijn een invoeging van $P$ (die een oudere ,Vorlage” voor zich had) om de Sabbat te „begründen”. Wij kunnen dit en in elk geval niet zo zeggen. Dat anderzijds Gen. 1 langzamerhand gegroeid is wordt ook door Ridderbos niet a priori als verwerpelijk beschouwd. De „leer” van Gen. 1 kan ,,angereichert” zijn60). Maar áls dit zo zou zijn, dan helpt het ons toch niet om de zes dagen uit de tekst te verwijderen, want we moeten op ons standpunt die gegroeide en ,angereicherte" tekst aanvaarden als de ons van God geschonkene! Ons zijn geen „Vorlagen” geopenbaard, maar de onder Gods voorzienig bestel overgeleverde tekst.

Maar als we nu ook deze verklaring niet kunnen aanvaarden, wat is er dan voor verklaring?

Ik meen dat er geen verklaring in stricte zin is. We moeten eindigen met een non liquet. Hoe komt dit? Zochten we iets verkeerds? Of zochten we op verkeerde wijze? Is er wel overeenstemming te verwachten tussen Gen. I en de natuurwetenschapen? En van wie moeten we dat verwachten? Van de theologen, van de exegeten? Of van de natuurkundigen? Op deze vragen antwoord ik: God geeft in Gen. 1 openbaring over een w o $\mathbf{n}$ d e r w e r k van Zijn hand. Deze openbaring is door God in verschillende opzichten begrensd en moest begrensd worden. Ze is niet adaequaat en kan dat niet zijn. Toch is die openbaring waar. De wetenschapt $z$ o e k t naar waarheid, naar de ware toedracht van zaken, in dit geval naar de ware toedracht van een wonderwerk Gods. Maar de wetenschap zal nooit toekomen aan Gen. 1, want dan zou ze een geloofszaak begrijpelijk gemaakt hebben.

Zeker zal de wetenschap steeds verder komen-in kennis! Maar ook in raadselen, want elke oplossing brengt nieuwe problemen mee. Op verschillende vragen kan misschien nog een antwoord komen. Maar hoe ver de wetenschap ook kome-ze zal nooit Gen. 1 kunnen ratificeren als juist, want dan zou het schepsel zijn Schepper hebben ingehaald!

Genesis 1 is de $1 \mathrm{i} \mathrm{mie} \mathrm{t,} \mathrm{waartoe} \mathrm{de} \mathrm{menselijke} \mathrm{kennis} \mathrm{kan} \mathrm{naderen,}$ maar die de mensen nooit zullen kunnen bereiken.

Nooit door kennis-

Alleen door het geloof-Hebr. 11:3-en in aanbidding van Hem, die hemel en aarde geschapen heeft.

J. H. KROEZE.

1) Dr. Nic. H. Ridderbos, Beschouwingen ovcr Genesis I. Hummelen. Assen. 1954. 
W. Nieboer Sr. Opmerkingen over Genesis I. Jan Haan. Groningen. 1955.

2) Theolog. Zeitschrift, Jan./Feb. 1956.

3) in The Torch Bible Commentaries, 1955.

4) in Die Kirchl. Dogmatik, III, 1.

5) The Revelation in the Wilderness.

6) Prophezei.

7) Schöpfung und Fall.

8) Das Christuszeugnis des AT.

9) Die Botschaft des A.T.

10) Gods Woord en der Eeuwen Getuigenis, 3e dr 1936, Kampen. bladz 106, 111 en v.

11) Bulletin of the American Schools of Oriental Research. Apr. 1956.

12) Gen. 11:26. Dit vs. zal wel niet betekenen dat Abram, Nahor en Haran tegelijk geboren zijn, maar ongeveer op zeventigjarige lceftijd kreeg Terah zonen, van wie Abram zeker de oudste was.

13) Gen. 5:32. Dit vs. moet als 11:26 (zie vorige noot) verstaan worden.

14) Bijbelsch Handboek. 1935. Kok. Kampen. pag. 111, 112.

15) Ruth Moore. In het Spoor van de Mens. zonder jaartaal. Becht. Amsterdam. Oorspronkelijke titel: Man, Time and Fossils. Voor Nederland bewerkt door P. van der Kruk. pag. 398, 415, 420, 425.

16) De titel van deze lezing, mij van bevriende zijde in afschrift ter lezing gegeven is: Prolegomena op de exegese van Genesis $I$.

17) De Grenzen der Wetenschap. Interfacultaire voordrachten in 1955 gehouden aan de Vrije Universiteit. Kok. Kampen. pag. 25 en v.

18) De Biblia Hebraica ed. Kittcl, editio octava vermeldt bij Gen. 1:I de lezingen: Orig. Brésith vel Baréséth, -seth; Samâr Barasjeet.

19) Jonker. a.w. pag. 30

20) Noordtzij a.w. bl. 115, 116.

21) Prof. dr. G. Ch. Aalders. De Goddelijke Openbaring in de eerste drie hoofstukken van Genesis. Kok. Kampen. 1932. pag. 211.

22) a.w. pag. 26.

23) Aalders a.w. pag. 263.

24) Ridderbos a.w. pag. 27.

25) Nieboer. a.w. Fag. 30.

26) Nieboer. a.w. pag. 34.

27) Nieboer. a.w. pag. 35.

28) Nieboer. a.w. pag. 41.

29) Nieboer. a.w. pag. 41.

30) Nieboer. a.w. pag. 42.

31) G. W. Freytagii Lexicon Arabico-Latinum. 1830. sub vece $t \mathbf{h ~ j}$.

32) Gordon. Ugaritic Handbook. Roma. 1947. deel III, pag. 276.

decl II, pag. 148: pnh. s.nps.lbit (15)thw.

In zijn: Ugaritic Literature, Roma 1949, pag. 39 vertaalt hij deze woorden met: (Prepare him) a sheep (for) the soul of the lioness of the $c h$ a os (lbu, leeuw en de vrouwel. vorm zijn ook godenaanduidingen. -schaap.pn(h) conf. Hebr. paniem, voor het aangezicht van..... plaatsen? 
33) Köhler-Baumgartner. Lexicon in Veteris Testamenti Libros, Leiden. 1953. sub voce.

34) Ridderbos. a.w. pag. 28.

35) Aalders. a.w. pag. 247.

36) Aalders. a.w. pag. 246, met beroep op Bavinck, Dogmatiek, 1I, pag. 32.

37) E. Sauer. Vom Adel des Menschen. Gütersloh. 1948. pag. 50-55.

38) Noordtzij. a.w. pag. 111.

39) Ridderbos. a.w. pag. 29

40) Sauer. a.w. pag. 50-70.

41) Aalders. a.w. pag. 247, 248, 263.

42) Aalders. a.w. pag. 254.

43) Aalders. a.w. pag. 262.

44) Aalders. a.w. pag. 231, 232.

45) Noordtzij. a.w. pag. 117

46) Noortzij. a.w. pag. 119.

47) Aalders. a.w. pag. 232 en v.

48) Ridderbos. a.w. pag. 24.

49) Men vergel. op dit punt ook Gunkel. Genesis. 1922. (in Gottinger Handkommentar) pag. 118

50) Ridderbos. a.w. pag. 25 en 26.

51) Ridderbos. a.w. pag. 20.

52) Ridderbos. a.w. pag. 17.

53) vergel. Aalders. a.w. pag. 232.

54) Nieboer. a.w. pag. 71 .

55) Nieboer. a.w. pag. 44, 57, 58, 60, 61, 68, 101, - 102, 103.

56) Nieboer. a.w. pag. 65.

57) Het woord „operatio" is door Nicboer bij Abaelardus gevonden. a.w. pag. 65.

58) Aalders. a.w. pag. 247.

59) Holzinger, Genesis. pag. 5 (in Kurzer Hand-Commentar).

60) Gunkel a.w. pag. 106, 118.

61) Ridderbos. a.w. pag. 10, 16. 